\title{
Biological response to iron fertilization in the eastern equatorial Pacific (IronEx II). II. Mesozooplankton abundance, biomass, depth distribution and grazing
}

\author{
G. C. Rollwagen Bollens ${ }^{1, *}$, M. R. Landry ${ }^{2}$ \\ ${ }^{1}$ Department of Integrative Biology, University of California at Berkeley, Berkeley, California 94720, USA \\ ${ }^{2}$ Department of Oceanography, University of Hawai'i at Manoa, Honolulu, Hawai'i 96822, USA
}

\begin{abstract}
Mesozooplankton (202 to $2000 \mu \mathrm{m}$ ) biomass, abundance, taxonomic composition, depth distributions and gut pigment contents were measured inside and outside of an iron-enriched patch during the IronEx II study in the eastern equatorial Pacific. Mean carbon biomass remained nearly constant in the ambient community, but increased 2- to 3-fold during early stages of the phytoplankton bloom. The increases were due primarily to small calanoid and cyclopoid copepods and copepod nauplii in the mixed layer and appeared to be the result of 2 processes. First, significantly higher abundances of nauplii in the patch indicated that adult copepods responded reproductively, at least initially, to the increased food. Second, changes in copepod vertical migratory behaviors in response to reduced light penetration and increased food abundance in the patch apparently resulted in an upward displacement of copepods from the lower euphotic zone into the mixed-layer. Mesozooplankton gut pigment content also increased significantly inside the patch, largely in proportion to the increased concentration of phytoplankton chlorophyll $a$, and estimates of carbon consumed suggest that mesozooplankton standing stock was growing at maximal, or near maximal, temperaturedependent rates $\left(1.0 \mathrm{~d}^{-1}\right)$ at the peak of the patch bloom. Nonetheless, zooplankton abundance and biomass declined, rather than increased, during this period. The premature decline of mesozooplankton in the patch suggests that they might have been cropped by their predators in a tightly coupled trophic network or that their reproductive output may have failed to produce viable young when the food resources were dominated by diatoms.
\end{abstract}

KEY WORDS: Biomass $\cdot$ Abundance $\cdot$ Vertical migration $\cdot$ Community structure $\cdot$ Gut pigment

\section{INTRODUCTION}

In the classic seasonal production cycle of temperate marine ecosystems, phytoplankton bloom in the springtime when nutrients mixed into surface waters by winter storms can be utilized under favorable conditions of increasing light and water-column stratification. Mesozooplankton are generally at low concentrations at this time of year and need to recover physiologically from winter diapause or nutritional deprivation. Their growth and reproductive responses to increasing food concentration are further slowed by low temperature. Consequently, even at modest

*E-mail: grollwag@socrates.berkeley.edu growth rates, a substantial biomass of phytoplankton can accumulate, deplete nutrients to low levels, and often sink as senescent aggregates before the algae are effectively grazed.

In planning for the IronEx II mesoscale iron-fertilization experiment, we recognized that initial conditions in the eastern equatorial Pacific would be quite unlike those preceding classic temperate blooms and could potentially allow a more dramatic mesozooplankton response to increased phytoplankton standing stock and production. First, the water would be stocked with an established community of grazing plankton, presumably in good physiological condition and already growing and reproducing at modest to high rates. Second, the elevated water temperatures in the equatorial Pacific 
would allow extremely high potential rates of growth and reproductive response. According to the empirical equations of Huntley \& Lopez (1992), for instance, generation times of copepods at $28^{\circ} \mathrm{C}$ and non-limiting food concentration should be on the order of $4.5 \mathrm{~d}$ and mean growth rates of individual animals would be as high as $1.0 \mathrm{~d}^{-1}$. Given such rates, a daily doubling of grazing impact was well within the hypothetical potential of mesozooplankton should the equatorial phytoplankton bloom in response to iron-fertilization.

In addition to enhanced physiological and reproductive potentials, anecdotal evidence from the IronEx I study also suggested that mesozooplankton might accumulate in an iron-induced patch as animals made forays into the mixed-layer from the lower euphotic zone or deeper depths, sensed the more-favorable food environment and stayed (Martin et al. 1994). Hypothetically, the 2-layer flow of the equatorial divergence cell would contribute to this effect by continuously refreshing the community of mesozooplankton below the mixed-layer.

The present study provides the first detailed account of mesozooplankton community responses to an ironfertilized bloom. To test for the expected large mesozooplankton response to iron-enhanced production, we investigated temporal changes in population abundances, taxonomic composition and total and size-fractioned biomass from daytime and nighttime sampling in and out of the IronEx II patch (Coale et al. 1996, Landry et al. 2000, in this issue). To evaluate the potential for significant accumulation of migrants into the patch from below, we also examined the depth structure of zooplankton populations. Lastly, as an index of changing grazing impact on the phytoplankton community, biomass-specific grazing rates were determined from measured estimates of gut pigment content and conservative assumptions about gut evacuation rates and digestive pigment destruction.

\section{MATERIALS AND METHODS}

Sample collection. Mesozooplankton samples were collected inside and outside the IronEx II patch near midday or midnight with a $1.0 \mathrm{~m}^{2}$ rectangular plankton net, equipped with a Brancker Time-Depth-Temperature Recorder and a General Oceanics flow meter (Landry et al. in press). A $64 \mu \mathrm{m}$ mesh net was used through Julian Day (JD) 157. Subsequently, a $202 \mu \mathrm{m}$ mesh net was used for sample collections inside the patch due to increased phytoplankton biomass. Prior to this switch, coincident sampling using 202 and $64 \mu \mathrm{m}$ mesh nets showed no significant difference in abundance or taxonomic composition of the $>200 \mu \mathrm{m}$ zooplankton community. The net was towed obliquely to the base of the mixed layer and back to the surface at each deployment. Mixed-layer depth was defined as the point at which temperature began to change by $>0.3^{\circ} \mathrm{C} \mathrm{m}^{-1}$, as measured by daily profiles with a SeaBird SBE9/11 CTD with SEASOFT software.

The collected zooplankton samples were immediately narcotized with carbonated water (Kleppel \& Pieper 1984) and split once using a Folsom plankton splitter. One-half of the sample was preserved in $4 \%$ borate-buffered formalin for later microscopical analyses. The other half of the sample was wet-sieved over a nested set of 2000,500, 202 and $64 \mu \mathrm{m}$ Nitex mesh filters to produce 4 size fractions: > 2000, 500-2000, 202-500 and 64-202 $\mu \mathrm{m}$. Each size fraction was then split again. One-half of this split was gently filtered over a pre-weighed $47 \mathrm{~mm} 64 \mu \mathrm{m}$ Nitex filter, rinsed with isotonic ammonium formate (to remove salts), desiccated at $60^{\circ} \mathrm{C}$ and stored in individual petri dishes for later determination of total dry weight and carbon biomass. The other half of the split was filtered over a $47 \mathrm{~mm}$ Whatman GF/F glass-fiber filter, rinsed with ammonium formate, wrapped in foil and immediately frozen in liquid nitrogen for shipboard analysis of community gut fluorescence.

In addition to the oblique tows of the mixed layer, depth-stratified vertical tows of the euphotic zone were conducted periodically during the day and night both inside and outside the iron-infused patch. Five overlapping vertical hauls were taken using a $0.5 \mathrm{~m}$ diameter paired bongo net system with $64 \mu \mathrm{m}$ mesh nets (Landry et al. 1994a). Each series produced duplicate samples from 5 depth strata: 0-30, 30-60, 60-90, 90-120, and 120-200 m. The total codend contents from these net tow samples were preserved in $4 \%$ borate-buffered formalin.

Biomass. Mesozooplankton carbon biomass was measured from the dried subsamples in each size fraction of the mixed-layer oblique tows. Upon return to the laboratory, the filters plus total samples were weighed using a Mettler AE160 electronic microbalance, and the weight of the filter was subtracted to obtain total dry weight. Each dried zooplankton sample was then homogenized using an ethanol-cleaned mortar and pestle, and 2 subsamples were removed, weighed and wrapped in pre-combusted foil. The foil boats were then individually combusted in a PerkinElmer model $2400 \mathrm{CHN}$ Elemental Analyzer. The carbon biomass $\left(B, \mathrm{mg} \mathrm{C} \mathrm{m}^{-3}\right)$ for each size fraction was computed as follows:

$$
B=C_{\text {sub }} \times W_{\text {Tot }} \times W_{\text {sub }}^{-1} \times 2^{s} \times V^{-1}
$$

where $C_{\text {sub }}$ is the mean measured carbon content of the subsample, $W_{\text {Tot }}$ and $W_{\text {sub }}$ are the total and subsample dry weights, $s$ is the number of splits of the total zooplankton sample, and $V$ is the volume of water sampled with the net tow. Total mesozooplankton carbon 
biomass was estimated from the combined biomass values from the 202-500 and 500-2000 $\mu \mathrm{m}$ size fractions. Biomass in the 64-202 $\mu \mathrm{m}$ fraction could not be accurately determined due to contamination from large phytoplankton during the bloom.

Abundance and taxonomic composition. Total abundance and taxonomic composition of the 202 to $2000 \mu \mathrm{m}$ mesozooplankton community were determined from all preserved samples from the mixedlayer oblique tows and the vertical bongo series. Mixed-layer samples were separated into 202-500 and 500-2000 $\mu \mathrm{m}$ size fractions before subsampling and enumeration. The size-fractioned samples were suspended in $500 \mathrm{ml}$ of filtered seawater and subsampled using a $5.0 \mathrm{ml}$ Stempel pipette. These subsamples were counted for total abundance, and each organism was identified to at least class or order. The vertical tow samples were subsampled and analyzed similarly; however, the entire 202-2000 $\mu \mathrm{m}$ fraction was counted and the copepods were identified to the genus level and naupliar or copepodite stage. All counts and identifications were made using a Wild M5 binocular dissecting microscope at 25 to $50 \times$ magnification. Copepod identification and taxonomy was according to Yamaji (1979).

Using the total mesozooplankton abundances obtained from each series of overlapping vertical tows, weighted mean depths (WMD, m) were calculated according to Bollens et al. (1993):

$$
W M D=\sum\left(A_{i} \times M_{i} \times H_{i}\right) / \sum\left(A_{i} \times H_{i}\right)
$$

where $i$ is the depth stratum, and $A$ the total abundance of mesozooplankton, $M$ the mid-point depth, and $H$ the vertical range $(m)$ of each depth stratum.

Gut pigment content. Mesozooplankton ingestion of phytoplankton was determined from the oblique mixed-layer tows inside and outside the iron-infused patch using the gut fluorescence method (Mackas \& Bohrer 1976). All gut pigment analyses were completed within 48 to $72 \mathrm{~h}$ of sample collection. Three equal random subsamples of the zooplankton community were obtained from each frozen filter using a hand-held hole punch and ground in $90 \%$ acetone in a tissue homogenizer to extract gut pigments. The extract was analyzed on a Turner model 10-AU Fluorometer for chlorophyll a (chl a) and phaeopigment concentrations (Strickland \& Parsons 1972). Weightspecific gut pigment content $\left(G P_{\mathrm{B}}, \mu \mathrm{g}\right.$ pigment $\left.\mathrm{mg} \mathrm{C}^{-1}\right)$ was calculated as:

$$
G P_{\mathrm{B}}=G P_{\mathrm{sub}} \times A_{\mathrm{Tot}} \times A_{\mathrm{sub}}{ }^{-1} \times 2^{s} \times V^{-1} \times B^{-1}
$$

where $G P_{\text {sub }}$ is the concentration of gut pigment from the subsample, $A_{\text {Tot }}$ and $A_{\text {sub }}$ are the total and subsampled areas of the filter, $s$ is the number of splits of the zooplankton sample, $V$ is the volume of water sampled, and $B$ is the carbon biomass $\left(\mathrm{mg} \mathrm{C} \mathrm{m}^{-3}\right)$ of the sample To be consistent with biomass estimates, total weightspecific gut pigment content of the mesozooplankton was computed as the weighted average of the 202-500 and 500-2000 $\mu \mathrm{m}$ gut pigment values.

Gut pigment content was determined using only the phaeopigment measurements from each mixed-layer oblique tow in order to minimize potential chlorophyll contamination from large diatoms as the bloom progressed. Fluorometric analyses of discrete water column samples collected daily from inside the patch indicated very low levels of phaeopigment relative to chl a throughout the experiment (M. Ondrusek \& R. Bidigare unpubl. data). In addition, gut phaeopigment concentrations were assumed to be a conservative index of ingested phytoplankton since no correction was made for degradation of chlorophyll to non-fluorescent products during gut passage. Literature estimates of pigment loss range from 0 to $100 \%$ of ingested chlorophyll (e.g. Conover et al. 1986, Lopez et al. 1988, Penry \& Frost 1991, Head \& Harris 1992, Mayzaud \& Razouls 1992).

Grazing rate estimates. In order to estimate ingestion rates of phytoplankton from the gut pigment measurements, 2 gut evacuation experiments were conducted at outside stations during IronEx II. Reliable experiments could not be conducted using zooplankton samples taken inside the enriched patch because high phytoplankton concentrations in the net prevented quantitative transfer of organisms to sample bottles in sufficient time to avoid significant gut evacuation. Mesozooplankton were collected at night in separate oblique tows in the manner described above. The live samples were immediately size-fractioned, and equal aliquots from each size fraction were transferred to 8 Nalgene bottles containing $300 \mathrm{ml}$ of $0.2 \mu \mathrm{m}$ filtered seawater. Every 5 to $8 \mathrm{~min}$ the contents of one bottle from each size fraction was filtered over a $24 \mathrm{~mm}$ GF/F filter and frozen for subsequent analysis of gut pigments as described above. Gut clearance rate constants $\left(\mathrm{h}^{-1}\right)$ were calculated from the decline in gut pigment (chlorophyll + phaeopigments) over a 30 to 45 min period, assuming an exponential rate of decay (Dam \& Peterson 1988).

Mesozooplankton grazing rates $(G, \mathrm{mg}$ phaeopigment $\mathrm{m}^{-3} \mathrm{~d}^{-1}$ ) were estimated as follows:

$$
G=G P_{\mathrm{B}} \times C R \times B^{-1}
$$

where $G P_{\mathrm{B}}$ is gut pigments content for each sample, $C R$ is the gut clearance rate $\left(\mathrm{h}^{-1}\right)$, and $B$ is the carbon biomass $\mathrm{m}^{-3}$ of mesozooplankton sampled in each net tow. Mesozooplankton community rates were obtained by combining the grazing rate estimates for the 202-500 and 500-2000 $\mu \mathrm{m}$ size fractions. Depth-integrated grazing rates (mg gut pigment $\mathrm{m}^{-2} \mathrm{~d}^{-1}$ ) were 
next calculated by multiplying $G$ times the mixedlayer tow depth. Finally, daily rates of mesozooplankton grazing impact ( $\%$ chl a consumed $\mathrm{d}^{-1}$ ) were calculated as the depth-integrated mesozooplankton community grazing rate divided by the standing stock of total chl a integrated to the depth of the mixed-layer tow.

\section{RESULTS}

\section{Mesozooplankton biomass and abundance}

Over the course of the experiment, mesozooplankton were sampled in 22 oblique tows in the surface mixed layer and 8 series of overlapping vertical bongo tows to $200 \mathrm{~m}$. Mixed-layer samples were distributed as 5 day and 5 night collections out of the patch and 5 day and 7 night tows in the patch. The vertical tows included 3 day and 1 night series out of the patch and 2 day and 2 night series in the patch. Mixed-layer depth increased from $25 \mathrm{~m}$ on JD 148 to approximately $55 \mathrm{~m}$ on JD 165.

Despite the water drift of up to $50 \mathrm{~km} \mathrm{~d}^{-1}$, mean carbon biomass of 202-2000 $\mathrm{mm}$ mesozooplankton remained fairly constant outside the patch during the day, with a community mean ( \pm standard deviation) of $3.4( \pm 0.8) \mathrm{mg} \mathrm{C} \mathrm{m}{ }^{-3}$. Nighttime community biomass was slightly higher and more variable, with a mean of $4.2( \pm 2.6) \mathrm{mg} \mathrm{C} \mathrm{m}{ }^{-3}$. Mesozooplankton biomass in the patch exceeded outside measurements between JDs
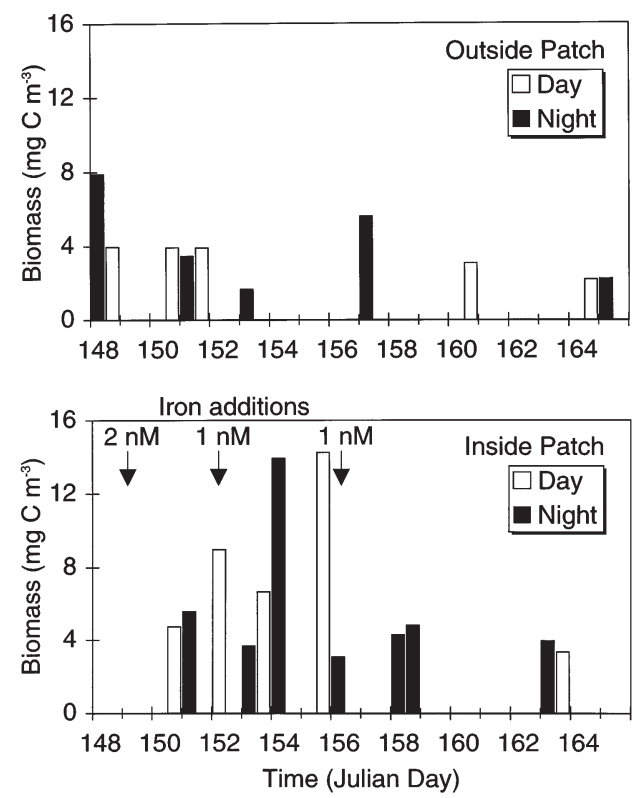

Fig. 1. Mesozooplankton $(202-2000 \mu \mathrm{m})$ carbon biomass from mixed-layer samples collected outside and inside the IronEx II patch
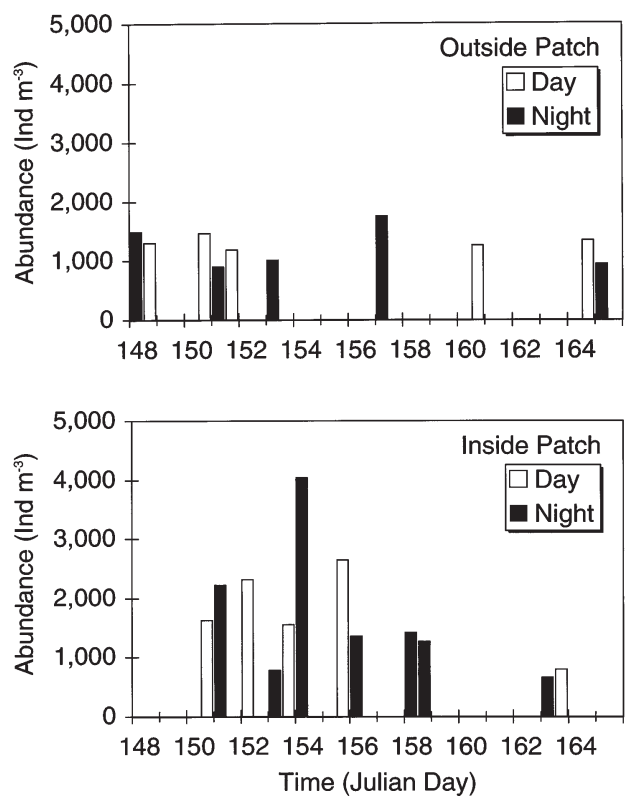

Fig. 2. Mesozooplankton (202-2000 $\mu \mathrm{m})$ abundance from mixed-layer samples collected outside and inside the IronEx II patch

150 and 155 , but the two were not substantially different thereafter (Fig. 1). Mean biomass estimates in the patch were $7.6( \pm 4.3)$ and $5.6( \pm 3.8) \mathrm{mg} \mathrm{C} \mathrm{m}^{-3}$ for day and night tows, respectively. The highest levels, approximately $14 \mathrm{mg} \mathrm{C} \mathrm{m}{ }^{-3}$, were from day and night tows on JDs 154 to 155.

Total mesozooplankton abundance outside the patch also remained steady over the duration of the experiment, with day and night means of $1300( \pm 110)$ and $1200( \pm 380)$ organisms $\mathrm{m}^{-3}$, respectively. Similar to the biomass trend, abundances were higher inside the patch from JDs 150 to 155 but decreased rapidly to outside levels thereafter (Fig. 2). Mean day and night abundances in the patch were $1800( \pm 720)$ and 1700 $( \pm 1200)$ individuals $\mathrm{m}^{-3}$. The highest zooplankton densities (night $=4000$, day $=2700$ individuals $\mathrm{m}^{-3}$ ) were obtained on JDs 154 and 155.

Size-fractioned biomass and abundance estimates of mesozooplankton closely followed the trends observed for the total mixed-layer community. While both size fractions showed numerical enhancement, the 202-500 $\mu \mathrm{m}$ mesozooplankton accounted for the bulk of the changes in both biomass and abundance in the patch versus outside values (Table 1). Small mesozooplankton more than doubled in biomass, and their abundance increased by $40 \%$ over ambient levels. In contrast, the 500-2000 $\mu \mathrm{m}$ component of the community increased by $41 \%$ in biomass and only $10 \%$ in abundance.

One-sided $t$-tests were performed to compare mixed-layer means in mesozooplankton biomass and 
Table 1. Mean carbon biomass $\left(\mathrm{mg} \mathrm{C} \mathrm{m}^{-3}\right)$ and abundance (individuals $\mathrm{m}^{-3}$ ) of mesozooplankton in the 202-500 and $500-2000 \mu \mathrm{m}$ size fractions. Means (standard deviations) are calculated from all mixed-layer oblique tows collected outside and inside of the IronEx II patch

\begin{tabular}{|c|c|c|c|c|}
\hline & \multicolumn{2}{|c|}{$202-500 \mu \mathrm{m}$} & \multicolumn{2}{|c|}{$500-2000 \mu \mathrm{m}$} \\
\hline & Day & Night & Day & Night \\
\hline \multicolumn{5}{|c|}{ Biomass } \\
\hline In: & 4.1 (5.1) & $2.2(2.0)$ & $3.5(2.2)$ & 3.4 (1.8) \\
\hline Out: & $1.3(0.2)$ & $1.3(0.6)$ & $2.1(0.8)$ & $2.8(2.0)$ \\
\hline \multicolumn{5}{|c|}{ Abundance } \\
\hline In: & $1500(620)$ & 1310 (950) & $320(130)$ & $370(220)$ \\
\hline Out: & $1000(200)$ & $920(430)$ & $310(120)$ & $300(80)$ \\
\hline
\end{tabular}

abundance between day and night samples, as well as between samples taken in and out of the patch. Differences were considered statistically significant for p-values $<0.05$ and non-significant for $p$-values $>0.10$. Because the number of net hauls was small for most comparisons and included samples from the patch before the bloom started as well as after its peak, p-values between 0.05 and 0.10 were judged nonsignificant but suggestive. According to these criteria, there were no statistically significant differences between day and night biomasses or abundances, either inside or outside the patch. Further statistical tests of biomass and abundance differences were therefore made using combined day and night samples.

Mesozooplankton carbon biomass increased significantly inside the iron-infused patch relative to outside samples, both when day and night tows were combined and when only daytime means were compared (day + night: $p=0.027$; day only: $p=0.049$ ). A suggestive difference in biomass was also observed in both size fractions when all inside and outside samples were compared (202-500 $\mu \mathrm{m}$ day+night: $\mathrm{p}=0.069$; 500-2000 $\mu \mathrm{m}$ day + night: $\mathrm{p}=0.089$ ). Similarly, the elevation in mesozooplankton abundance inside the patch over ambient levels was non-significant but suggestive, as was the increased abundance in the 202-500 $\mu \mathrm{m}$ fraction (202 to $2000 \mu \mathrm{m}: \mathrm{p}=0.069$; 202-500 $\mu \mathrm{m}: \mathrm{p}=0.061)$. There was no significant difference between mean abundance in the 500-2000 $\mu \mathrm{m}$ fraction inside versus outside the patch for either day or night samples ( $\mathrm{p}>0.25)$.

\section{Taxonomic composition}

Copepods (including nauplii) were the dominant mesozooplankton both inside and outside the patch, comprising $>83 \%$ of all organisms enumerated from mixed-layer samples in the 202 to $2000 \mu \mathrm{m}$ size frac- tion. Calanoid copepods were consistently more abundant than cyclopoids, and harpacticoids were the least abundant of the 3 copepod orders. Representatives of 28 copepod genera were identified, with the highest abundances among Paracalanus, Oithona, Oncaea, Clausocalanus, Calanus, Calocalanus and Microsetella (Table 2). The remainder of the mesozooplankton community consisted of larvaceans, juvenile and larval euphausiids, chaetognaths and a small number of other taxa, including hyperiid amphipods, polychaete worms and siphonophores.

Abundances of the calanoid and cyclopoid copepods remained fairly constant outside the patch throughout the experiment, while the less abundant taxa showed greater variability. Both calanoid and cyclopoid copepods increased in the patch mixed layer by $30 \%$ over outside levels, but only the calanoid increase was marginally significant ( $t$-test: $\mathrm{p}=0.079$ ). Copepod nauplii and other mesozooplankton more than doubled in abundance inside the patch, both representing highly significant increases relative to the outside community

Table 2. Mean abundances of copepods (adults and advanced copepodids > $202 \mu \mathrm{m}$ ) identified in net samples from the upper $200 \mathrm{~m}$ during IronEx II. Genera are listed in order of mean abundance in samples collected in and out of the patch

\begin{tabular}{|c|c|c|c|}
\hline \multicolumn{2}{|c|}{ Outside patch } & \multicolumn{2}{|c|}{ Inside patch } \\
\hline Genus & No. $\mathrm{m}^{-3}$ & Genus $\quad \mathrm{N}$ & No. $\mathrm{m}^{-3}$ \\
\hline \multicolumn{4}{|l|}{ Order: Calanoida } \\
\hline Paracalanus & 1800 & Paracalanus & 1600 \\
\hline Clausocalanus & 830 & Clausocalanus & 660 \\
\hline Calanus & 520 & Calanus & 650 \\
\hline Calocalanus & 340 & Calocalanus & 550 \\
\hline Acrocalanus & 230 & Acrocalanus & 330 \\
\hline Acartia & 200 & мecynocera & 180 \\
\hline Mecynocera & 140 & Acartia & 160 \\
\hline Euchaeta & 52 & Eucalanus & 120 \\
\hline Eucalanus & 43 & Pleuromamma & 65 \\
\hline Pleuromamma & 31 & Euchaeta & 31 \\
\hline Lucicutia & 19 & Lucicutia & 26 \\
\hline Scolecithrix & 5 & Scolecithrix & 11 \\
\hline Rhincalanus & 2 & Rhincalanus & 7 \\
\hline Euchirella & 1 & Candacia & 5 \\
\hline Temora & $<1$ & Centropages & $<1$ \\
\hline Centropages & $<1$ & Euchirella & $<1$ \\
\hline Labidocera & $<1$ & Labidocera & 1 \\
\hline Aetideus & $<1$ & Heterorhabdus & $<1$ \\
\hline \multicolumn{4}{|c|}{ Order: Cyclopoida } \\
\hline Oncaea & 1300 & Oithona & 1200 \\
\hline Oithona & 1000 & Oncaea & 1000 \\
\hline Corycaeus & 220 & Corycaeus & 300 \\
\hline Lubbockia & 1 & Lubbockia & 6 \\
\hline Sapphirina & $<1$ & Sapphirina & $<1$ \\
\hline \multicolumn{4}{|c|}{ Order: Harpacticoida } \\
\hline Microsetella & 710 & Microsetella & 680 \\
\hline Clytemnestra & $<1$ & Clytemnestra & $<1$ \\
\hline Copepod nauplii & 190 & Copepod nauplii & i 600 \\
\hline
\end{tabular}



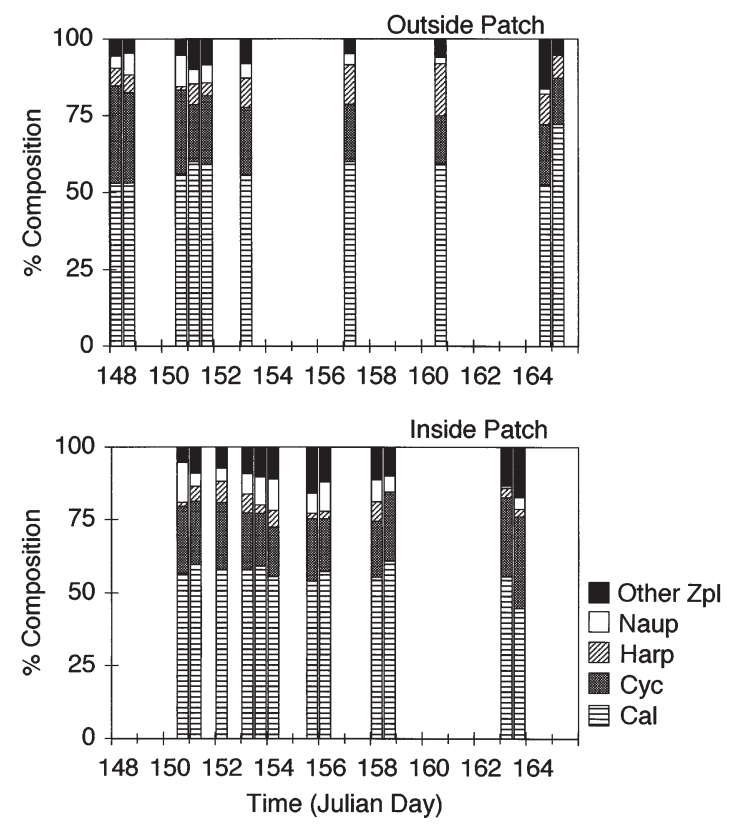

Fig. 3. Temporal changes in the relative composition of mesozooplankton taxa from mixed-layer net samples collected inside and outside the IronEx II patch

(nauplii: $\mathrm{p}=0.024$; other mesozooplankton: $\mathrm{p}=0.014$ ). Conversely, abundances of harpacticoid copepods decreased by $50 \%$ inside the mixed-layer patch. None of the taxonomic categories showed significant day/night differences in mean abundances either in or out of the patch (all p-values $\geq 0.10$ ).

The increased abundance of copepods and other mesozooplankton was almost entirely accounted for by animals in the 202-500 $\mu \mathrm{m}$ fraction (Table 3). Calanoid and cyclopoid copepods in this size fraction increased by $>35 \%$ inside the patch, while larger calanoids and cyclopoids did not increase appreciably relative to outside abundances. Harpacticoids decreased in both size fractions inside the patch compared to outside. However, the highest proportional increases in mesozooplankton abundance inside the patch came from highly significant 2- to 3-fold increases in the 202-500 and 500-2000 $\mathrm{\mu m}$ copepod nauplii and other zooplankton (all $\mathrm{p}$-values $\leq 0.03$ ). The latter were principally larvaceans, larval and juvenile euphausiids, and chaetognaths.

Despite the increased abundances of calanoid and cyclopoid copepods inside the patch, their contributions to total abundance remained generally constant and close to the proportions observed outside (Fig. 3). However, shifts in the relative proportions of harpacticoid copepods, nauplii, and other zooplankton inside the patch were evident. Harpacticoids decreased from $8 \%$ of the total mesozooplankton abundance outside the patch to $<4 \%$ inside. Nauplii and other mesozoo-
Table 3. Mean abundances (number $\mathrm{m}^{-3}$ ) of copepod orders, copepod nauplii and other mesozooplankton from the 202-500 and 500 to $2000 \mu \mathrm{m}$ size fractions in and out of the IronEx II patch. Parentheses contain standard deviations of the mean estimates

\begin{tabular}{|c|c|c|c|c|}
\hline \multirow[t]{2}{*}{ Taxon } & \multicolumn{2}{|c|}{$202-500 \mu \mathrm{m}$} & \multicolumn{2}{|c|}{ 500-2000 $\mu \mathrm{m}$} \\
\hline & Day & Night & Day & Night \\
\hline \multicolumn{5}{|c|}{ Calanoida } \\
\hline In: & 840 (390) & $761(560)$ & 150 & $200(100)$ \\
\hline Out: & $570(120)$ & $555(250)$ & $160(78)$ & $170(54)$ \\
\hline \multicolumn{5}{|c|}{ Cyclopoida } \\
\hline In: & $350(140)$ & $284(160)$ & 51 (25) & 44 (29) \\
\hline Out: & $240(81)$ & 222 (130) & $60(33)$ & 45 (19) \\
\hline \multicolumn{5}{|c|}{ Harpacticoida } \\
\hline In: & $42(52)$ & $52(42)$ & $19(12)$ & $28(40)$ \\
\hline Out: & $66(62)$ & 74 (67) & $32(20)$ & 34 (6) \\
\hline \multicolumn{5}{|c|}{ Nauplii } \\
\hline In: & $140(72)$ & $127(140)$ & $3(2)$ & $3(4)$ \\
\hline Out: & 70 (51) & $44(25)$ & $2(2)$ & $0(1)$ \\
\hline \multicolumn{5}{|c|}{ Other zooplankton } \\
\hline In: & $100(73)$ & $86(71)$ & $95(67)$ & $94(60)$ \\
\hline Out: & $52(64)$ & $26(16)$ & 55 (11) & 50 (13) \\
\hline
\end{tabular}

plankton increased from 5 to $8 \%$ and from 7 to $11 \%$, respectively. While always representing $<20 \%$ of the total $>202 \mu \mathrm{m}$ mesozooplankton abundance, nauplii and larvaceans were clearly enhanced inside the patch, but they declined to nearly ambient levels by JD 163 (Fig. 4).
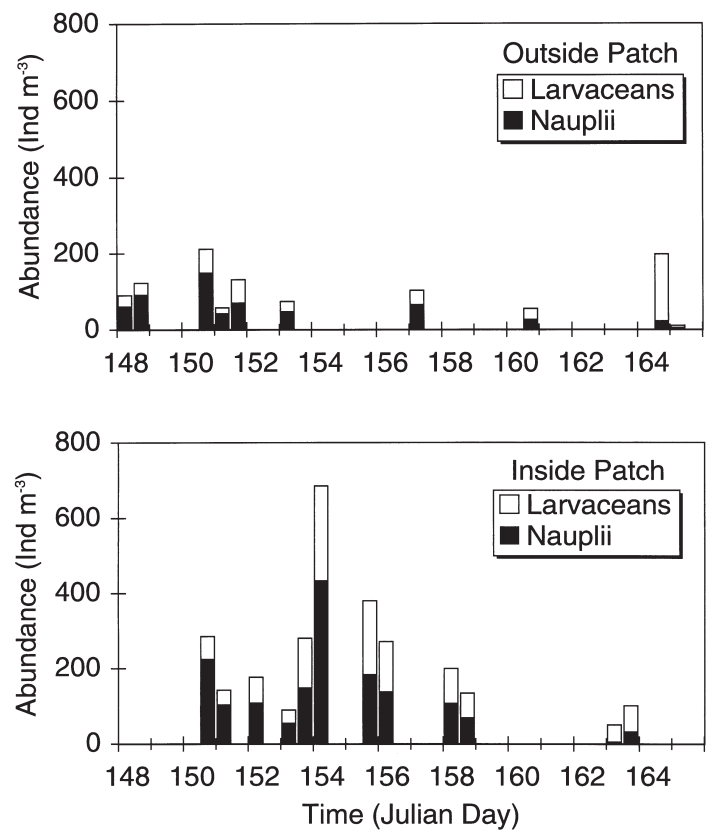

Fig. 4. Abundances of larvaceans and copepod nauplii from net samples collected outside and inside the IronEx II patch 

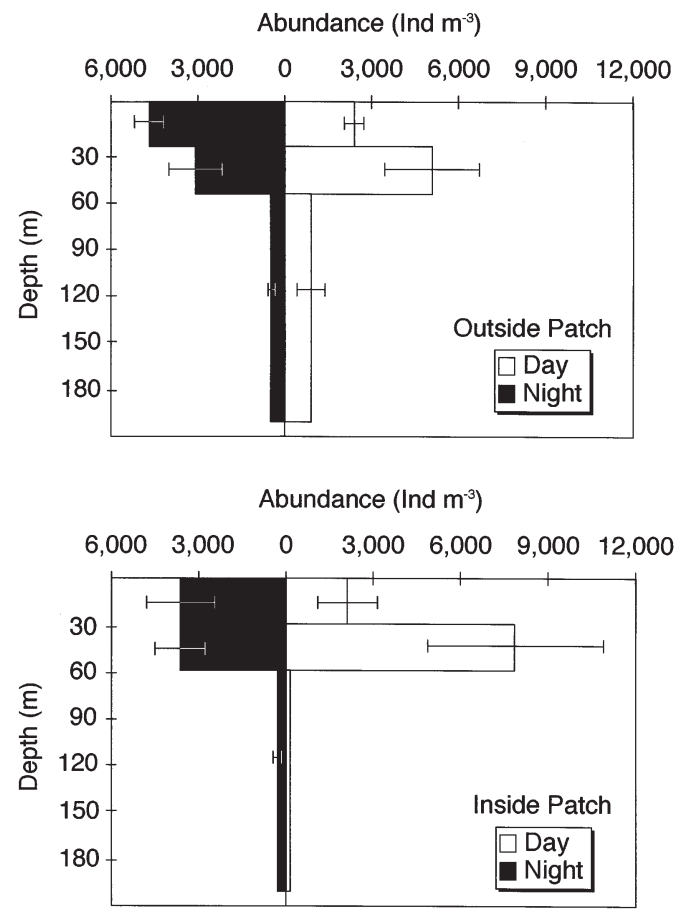

Fig. 5. Vertical distributions of mesozooplankton (202-2000 $\mu \mathrm{m})$ from overlapping net samples collected during the day and night, outside and inside the IronEx II patch. Error bars indicate $\pm 1 \mathrm{SE}$

\section{Vertical distributions}

Counts from the overlapping vertical tow series showed a change in the vertical structure of the mesozooplankton community in the upper $200 \mathrm{~m}$ inside the patch (Fig. 5). During the day outside the patch, mesozooplankton were distributed throughout the upper $200 \mathrm{~m}$. On average, $30 \%$ of the overall abundance was observed in the 0 to $30 \mathrm{~m}$ depth stratum, $56 \%$ in the $30-60 \mathrm{~m}$ stratum, and $15 \%$ below $60 \mathrm{~m}$. At night, $55 \%$ of the mesozooplankton were concentrated in the upper $30 \mathrm{~m}, 35 \%$ resided between 30 and $60 \mathrm{~m}$, and $10 \%$ were found below $60 \mathrm{~m}$. At the patch stations, however, mesozooplankton were concentrated almost entirely in the lower portion or just below the mixed layer during the day (>99\%), with $78 \%$ of the total organisms between 30 and $60 \mathrm{~m}$ and $22 \%$ in the upper $30 \mathrm{~m}$. The nighttime distribution underlying the patch followed a similar, though less dramatic pattern, with $51 \%$ of the organisms in the $30-60 \mathrm{~m}$ stratum, $45 \%$ in the upper $30 \mathrm{~m}$, and $4 \%$ below $60 \mathrm{~m}$.

In order to test whether the apparent shifts in mesozooplankton vertical distribution were statistically significant, the weighted mean depths of each vertical tow series were compared inside and outside the patch using 1 -sided $t$-tests. At night, the weighted mean depth inside the patch of $41 \mathrm{~m}$ was not significantly dif- ferent from the weighted mean depth of $49 \mathrm{~m}$ outside the patch $(p>0.10)$. During the day, the weighted mean depths in and out of the patch were 37 and $57 \mathrm{~m}$, respectively. While the difference was not statistically significant by conventional standards $(p=0.10)$, considering the very small sample sizes and the broad time-scale over which the tows were obtained, the test result suggests an upward shift in the daytime depth distribution of mesozooplankton inside the patch.

Fig. 6 shows day/night vertical distributions for each copepod order, combined copepod nauplii, and other mesozooplankton. During the day, each of the taxonomic categories were distributed similarly inside the patch, with $>60 \%$ of their abundances concentrated in the 30-60 m layer and the remainder of the population located in the upper $30 \mathrm{~m}$. Virtually no mesozooplankton were detected below $60 \mathrm{~m}$ under the patch during the daytime. At night, the copepods other than nauplii were distributed similarly to the overall mesozooplankton community inside the patch (Fig. 6). However, copepod nauplii and other mesozooplankton were principally concentrated in the $30-60 \mathrm{~m}$ stratum and were not present at all below $60 \mathrm{~m}$. Likewise, the vertical distributions of the dominant copepod genera were similar to the trend for the overall community (Fig. 7). In general, each genus of copepod showed slightly lower abundances in the upper $30 \mathrm{~m}$ and much lower abundances below $60 \mathrm{~m}$ inside the patch both

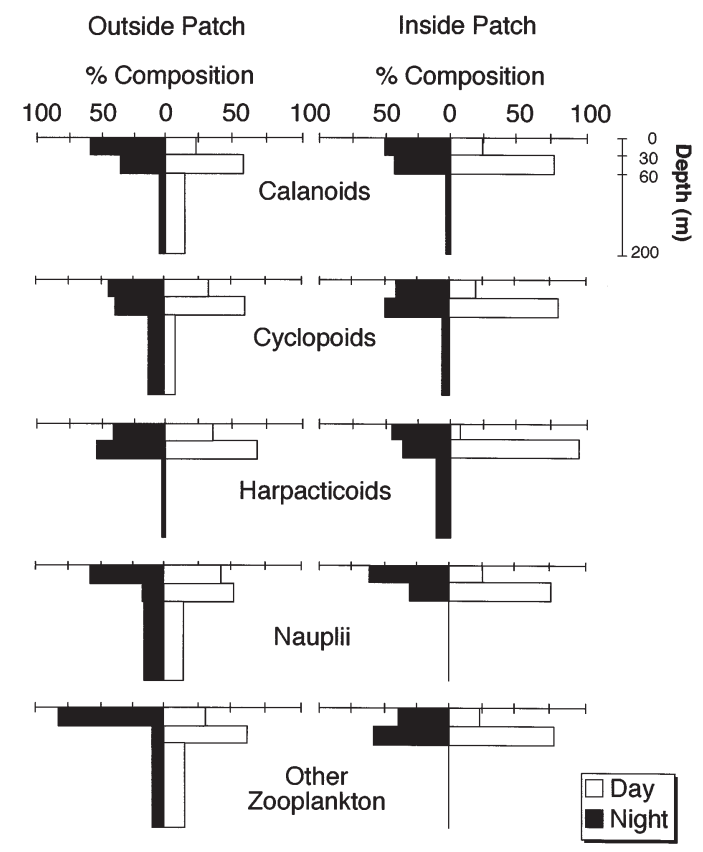

Fig. 6. Relative vertical distributions of adult and naupliar copepods and other mesozooplankton from overlapping net tows collected outside and inside the IronEx II patch 


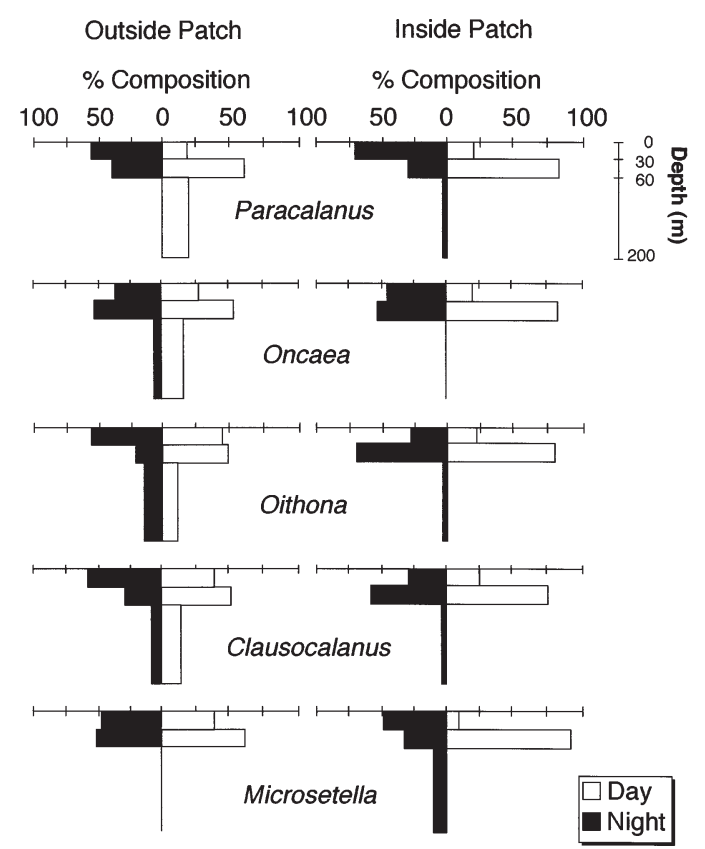

Fig. 7. Relative vertical distributions of the 5 most abundant copepod genera from overlapping vertical net samples collected from outside and inside the IronEx II patch

day or night. Nearly all copepod taxa increased in abundance between 30 and $60 \mathrm{~m}$ (Fig. 7).

The most notable relative increases were among the strongly migrating Pleuromamma and Eucalanus spp., which doubled and tripled, respectively, in the upper $60 \mathrm{~m}$. In addition, 3- to 5-fold increases were noted for other carnivorous genera such as Rhincalanus, Candacea and Temora although these genera never exceeded $1 \%$ of the total calanoid copepods collected. Calocalanus spp. increased nearly 2-fold above $60 \mathrm{~m}$ inside the patch. Oithona spp. increased between 30 and $60 \mathrm{~m}$ both day and night, but also decreased substantially above 30 and below $60 \mathrm{~m}$, such that its overall abundance over the $200 \mathrm{~m}$ water column did not change significantly.
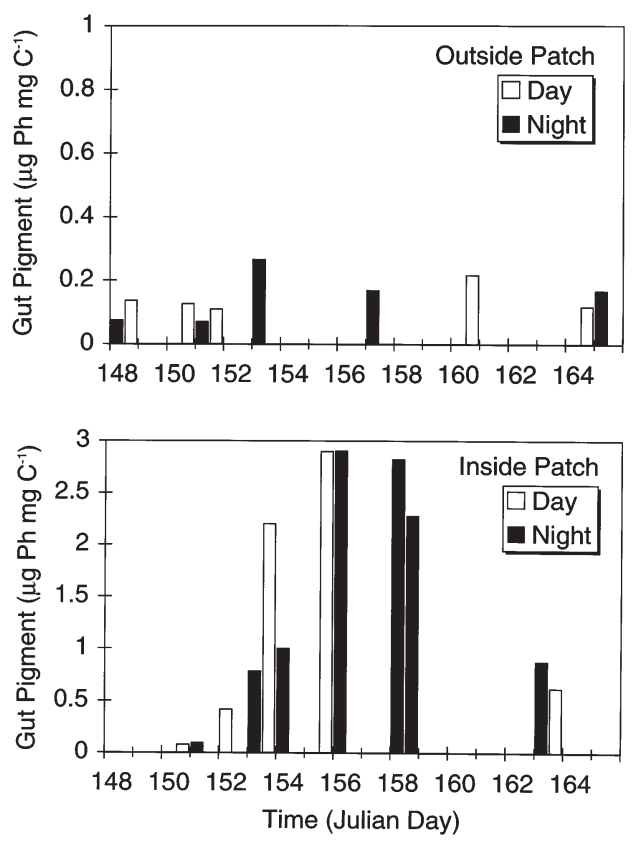

Fig. 8. Weight-specific gut pigment contents of mixed-layer mesozooplankton from outside and inside the IronEx II patch. Note $3 \times$ scale difference between figure panels

\section{Gut pigment content}

Gut fluorescence analyses from the mixed-layer samples showed that gut phaeopigment content increased substantially inside the patch relative to outside stations (Fig. 8). The ambient levels of weightspecific gut phaeopigment $(\mathrm{Ph})$ were $0.14 \quad( \pm 0.04)$ during the day and $0.15( \pm 0.08) \mu \mathrm{gh} \mathrm{mg} \mathrm{C} \mathrm{C}^{-1}$ during the night. Mesozooplankton community gut phaeopigment increased inside the patch to a daytime mean of $1.24( \pm 1.23) \mu \mathrm{g} \mathrm{Ph} \mathrm{mg} \mathrm{C}^{-1}$ and a nighttime mean of $1.54( \pm 1.11) \mu \mathrm{gh} \mathrm{mg} \mathrm{C}^{-1}$. The highest gut

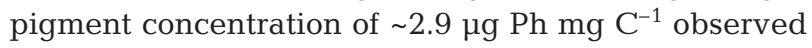
during the peak patch bloom (JDs 155 to 158, Landry et al. 2000) represents an approximately 21 -fold in-

Table 4. Mean estimates ( \pm standard deviation) of gut pigment content ( $\mu$ g phaeopigment $\mathrm{mg} \mathrm{C}^{-1}$ ), grazing rate (mg phaeopigment $\left.\mathrm{m}^{-3} \mathrm{~d}^{-1}\right)$ and grazing impact (\% chl a consumed $\mathrm{d}^{-1}$ ) for 202-500 and 500-2000 size fractions of mesozooplankton in and out of the IronEx II patch

\begin{tabular}{|llccccc|}
\hline \multirow{2}{*}{ Parameter } & & \multicolumn{2}{c}{$202-500 \mu \mathrm{m}$} & \multicolumn{2}{c|}{$500-2000 \mu \mathrm{m}$} \\
& & Day & $0.78(0.53)$ & Day & $0.87(1.08)$ & $0.75(0.59)$ \\
Gut pigment & In: & $0.37(0.31)$ & $0.07(0.04)$ & $0.09(78)$ & $0.08(0.04)$ \\
& Out: & $0.06(0.02)$ & $0.073(0.089)$ & $0.076(0.064$ & $0.110(0.117)$ & $0.114(0.077)$ \\
Grazing rate & In: & $0.004(0.001)$ & $0.004(0.002)$ & $0.009(0.003)$ & $0.009(0.005)$ \\
& Out: & $6.3(4.7)$ & - & $7.4(3.8)$ & $4.5(2.7)$ & - \\
\hline
\end{tabular}



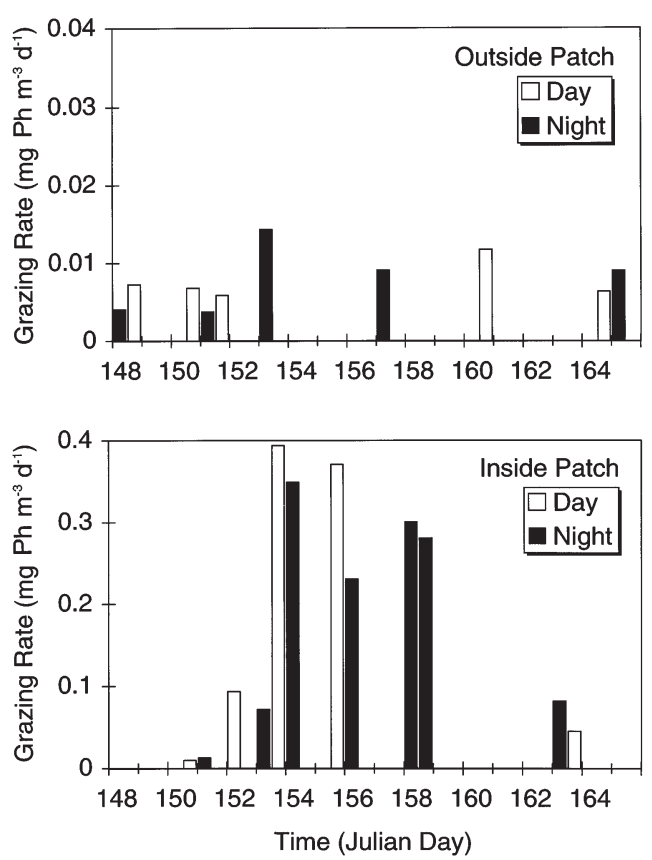

Fig. 9. Mesozooplankton grazing rate estimates from mixedlayer net tows outside and inside the IronEx II patch. Note $10 \times$ scale difference between figure panels

crease in carbon-specific gut $\mathrm{Ph}$ content over ambient levels $(\mathrm{p}<0.01)$.

Mesozooplankton size fractions showed similar patterns of increased gut pigment content inside the patch, with the 500 to $2000 \mu \mathrm{m}$ values generally 1.5 to 2 times higher than those of the 202 to $500 \mu \mathrm{m}$ fraction (Table 4). The small mesozooplankton showed a marginally significant $(p=0.064)$ difference between day and night gut pigment contents inside the patch, whereas the larger fraction demonstrated no day/night difference.

\section{Grazing rates and impacts}

The 2 gut evacuation experiments conducted during the present study yielded a mean clearance rate estimate of $2.3 \mathrm{~h}^{-1}$. Since this was comparable to the mean of 24 experiments reported by Zhang et al. (1995) from the US JGOFS (Joint Global Ocean Flux Study) EqPac Program at $140^{\circ} \mathrm{W}$, we used the latter, more robust estimate $\left(2.1 \mathrm{~h}^{-1}\right)$ for our rate calculations. This gut turnover rate was applied equally to gut pigment contents in and out of the patch and for both size fractions. Therefore, the resulting grazing rate estimates simply reflected the combined differences in biomass and biomass-specific gut pigment.

Grazing rate estimates from the patch indicated a 27-fold increase over ambient levels between JDs 153

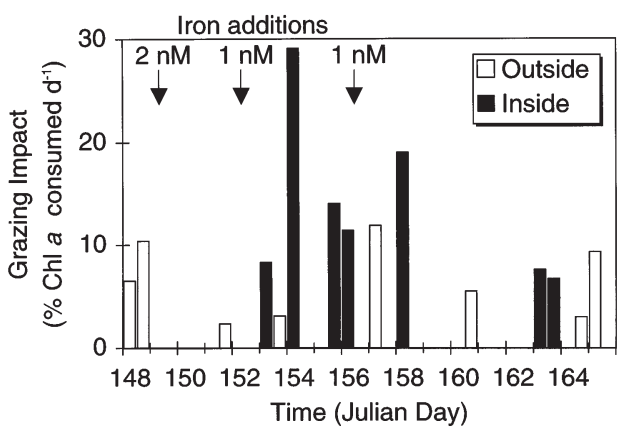

Fig. 10. Mesozooplankton grazing impacts outside and inside the IronEx II patch. Grazing impacts were calculated from the ratios of grazing rate $\left(\mathrm{mg}\right.$ phaeopigment consumed $\mathrm{d}^{-1}$ ) to concentration of phytoplankton chl $a$, both integrated to the depth of each mixed-layer net tow

and 158 (Fig. 9), with a maximum value of $0.39 \mathrm{mg} \mathrm{Ph}$ $\mathrm{m}^{-3} \mathrm{~d}^{-1}$ on JD 153. Mean day and night community grazing rates outside the patch were $0.013( \pm 0.004)$ and $0.013( \pm 0.007) \mathrm{mg} \mathrm{Ph} \mathrm{m} \mathrm{m}^{-3} \mathrm{~d}^{-1}$, respectively. Mean day $\left(0.183 \pm 0.185 \mathrm{mg} \mathrm{Ph} \mathrm{m} \mathrm{m}^{-3} \mathrm{~d}^{-1}\right)$ and night $(0.190 \pm$ $0.132 \mathrm{mg} \mathrm{Ph} \mathrm{m} \mathrm{m}^{-3} \mathrm{~d}^{-1}$ ) estimates were similar in the patch, and significantly elevated over outside estimates (Table 4).

The increase in grazing rate estimates in the IronEx II patch largely followed the increased concentration of total chl $a$, which plateaued at about 16 times higher than the ambient concentration from JDs 155 to 159 (Landry et al. 2000). Therefore, the mortality impact of mesozooplankton grazing on phytoplankton only doubled inside the patch compared to outside estimates (Fig. 10). The outside mean grazing impact was $6 \%$ of mixed-layer chl a standing stock $\mathrm{d}^{-1}$. The inside mean of $14 \%$ chl a d $\mathrm{d}^{-1}$ was significantly higher and punctuated by peaks $\geq 19 \% \mathrm{~d}^{-1}$ on JDs 154 and 158 (Fig. 10).

\section{DISCUSSION}

The IronEx II experiment was designed to test the hypothesis that iron deficiency limits the carbon and nutrient uptake of phytoplankton in the eastern equatorial Pacific (Coale et al. 1996). Although the iron hypothesis had been tested previously in a variety of incubation studies (e.g. Martin et al. 1991, Price et al. 1991) and in the shorter (9 d) IronEx I open-ocean enrichment experiment (Martin et al. 1994), none of these investigations specifically addressed the role of mesozooplankton in limiting the net growth of phytoplankton. This study thus represents the first quantitative assessment of the mesozooplankton community response to a mesoscale iron-stimulated phytoplankton bloom. 


\section{Temporal patterns in biomass and abundance}

During IronEx II, mixed-layer mesozooplankton biomass and abundance outside the iron-infused patch remained nearly constant over $18 \mathrm{~d}$ and $\sim 1500 \mathrm{~km}$ of drift from $4^{\circ} \mathrm{S} 104^{\circ} \mathrm{W}$ to $7^{\circ} \mathrm{S} 111^{\circ} \mathrm{W}$. The combined day/night biomass mean of $3.8 \mathrm{mg} \mathrm{C} \mathrm{m}{ }^{-3}$ is in close agreement with White et al. (1995), who found mean biomass of $\sim 3.6 \mathrm{mg} \mathrm{C} \mathrm{m}^{-3}$ over the same latitudinal range at $140^{\circ} \mathrm{W}$ during the EqPac Program. In the ironfertilized patch, mesozooplankton abundance and biomass increased by as much as 3 times higher than the ambient average, with maximum values observed between 4 and $5 \mathrm{~d}$ after the initial infusion (Figs. $1 \& 2$ ). These results supported our initial expectation that mesozooplankton would increase inside the patch relative to outside levels in response to an iron-stimulated phytoplankton bloom. The present evidence also provides some support to the view that the zooplankton reproductive response would be rapid and significant. Small $(202-500 \mu \mathrm{m})$ animals accounted for the majority of the mesozooplankton increase, with most attributable to small calanoid copepods, copepod nauplii and larvaceans (Fig. 4).

A rapid change in mesozooplankton biomass was also observed in the central equatorial Pacific during the EqPac Program following passage of a tropical instability wave (Roman et al. 1995). The instability wave apparently caused increased upwelling of iron into the euphotic zone at $140^{\circ} \mathrm{W}$ (Foley et al. 1997), resulting in an increase of chlorophyll and diatom-associated pigment biomass (Bidigare \& Ondrusek 1996). In response, mesozooplankton biomass increased nearly 5 -fold in the upper $200 \mathrm{~m}$ over a $10 \mathrm{~d}$ period. As in the present study, mesozooplankton biomass returned to normal levels soon after the instability wave-induced chlorophyll peak (Roman et al. 1995).

While at least some of the changes observed in the EqPac instability wave study might be ascribed to advective effects as the wave moved by the fixed sampling station, it is clear in the present study that the changes were mostly due to in situ processes. Therefore, the inability of the mesozooplankton to continue to grow rapidly in abundance and biomass during the period of peak bloom biomass needs some explanation. For one, it seems unlikely that the mesozooplankton voluntarily left the patch of enhanced food abundance. There is little evidence of a pronounced diel migratory behavior to remove animals from the mixedlayer on a regular cycle. In addition, the deepening of the mixed-layer bloom to include the depth range ( 0 to $60 \mathrm{~m}$ ) of most mesozooplankton, as well as the shoaling of isolumes due to increased patch biomass (see below), should both have worked to retain zooplankton in the patch.
The mesozooplankton decline during the peaks of the patch bloom would be consistent with strong predatory regulation of mesozooplankton standing stock. In this regard, the ecological setting for IronEx II phytoplankton bloom was substantially different from classic seasonal blooms in temperate environments in that the organisms involved were already growing, though not necessarily at maximal rates, and suffering losses to an established network of predators. Just as the high temperatures of equatorial waters should have allowed a rapid response of omnivorous zooplankton to increased abundances of large phytoplankton and heterotrophic protists (e.g. Huntley \& Lopez 1992), the same would be true for the predators of zooplankton.

Donaghay et al. (1991) proposed that zooplankton reproduction and/or growth rates might increase in response to increased food resources resulting from an atmospheric input of iron to an HNLC region. However, changes in zooplankton species composition, age class structure and biomass would only be observed if predation losses did not increase proportionally with the increased growth and reproduction. During IronEx II, the mixed-layer mesozooplankton community composition remained the same throughout the experiment, and biomass initially increased but then returned rapidly to pre-infusion levels. These results were consistent with the notion that the gains in mesozooplankton growth would be quickly lost to a predator community poised to consume them.

There is, however, another possible explanation of the zooplankton decline during the peak of the patch bloom - a failure in reproduction due to inhibitory effects or nutritional deficiency of an increased diatom diet on copepod embryonic development (e.g. Ianora et al. 1995, Laabir et al. 1995, Poulet et al. 1995). This mechanism is controversial, even in coastal environments where diatom blooms much higher than the IronEx patch occur (Ban et al. 1997, Jónasdóttir et al. 1998), and we have no direct evidence that it was important in the present study. Nonetheless, since the predicted results are consistent with our observations, a careful investigation of the grazer reproductive physiology and egg viability would be an important addition to future investigations of iron bloom responses in tropical waters. In colder HNLC systems (the subarctic Pacific or Southern Ocean), temperature effects or reproductive seasonality would likely preclude a significant reproductive response over the time period (2 to $3 \mathrm{wk}$ ) during which an iron-fertilized patch could be effectively studied.

\section{Vertical community structure}

The observed changes in vertical distributions of mesozooplankton suggest that their abundances may 
also have increased inside the patch as the result of altered vertical migrations in the upper $200 \mathrm{~m}$. The majority of mesozooplankton were found at or just below the base of the mixed-layer patch, whereas they were more equally distributed throughout the 3 depth strata outside the patch (Fig. 5). Since no significant difference was found in total $0-200 \mathrm{~m}$ abundance in and out of the patch, much of the increased daytime abundance in the 30-60 $\mathrm{m}$ depth stratum might have resulted from depletion in the density of mesozooplankton below $60 \mathrm{~m}$. At night, the contribution of organisms to the 30 to $60 \mathrm{~m}$ stratum was more pronounced from animals distributed above $30 \mathrm{~m}$ during the day.

Two factors may have resulted in the accumulation of mesozooplankton between 30 to $60 \mathrm{~m}$ at the patch station. First, discrete measurements of chl a concentration (Landry et al. 2000) and fluorescence profiles from daily CTD casts indicated that the chlorophyll maximum shifted from $\sim 10 \mathrm{~m}$ on JD 148 to $20-30 \mathrm{~m}$ at the peak of the bloom. Previous studies have noted the correspondence between depth distributions of zooplankton and chl a (Ortner et al. 1980, Townsend et al. 1984, Napp et al. 1988), or between zooplankton and primary production (Roman et al. 1986, Harrison 1990). In either case, the hypothesized benefit is proximity to increased food resources. The dominant taxa in the present study-Paracalanus, Clausocalanus, Calanus and Oithona spp. - are primarily herbivorous/omnivorous (Lampitt \& Gamble 1982, Dessier \& Donguy 1985), and Napp et al. (1988) have shown that the vertical distributions of all, except Paracalanus, maintain positive relationships with chlorophyll distributions in both day and night samplings.

The second factor that may have effected mesozooplankton vertical distribution was a change in light penetration, light being an important environmental cue for the diel migratory behaviors (Longhurst 1976). The extinction coefficient for photosynthetically available radiation $\left(K_{\mathrm{par}}\right)$ increased inside the patch from ambient levels of $\sim 0.06$ to $>0.13 \mathrm{~m}^{-1}$ on JD 155 , resulting in a shoaling of the euphotic zone (1\% light depth) from 72 to 33 m (Kudela \& Chavez 1996).

Substantially higher chlorophyll in the mixed layer could have caused a reduction in daytime downward migration of mesozooplankton to depths below $60 \mathrm{~m}$ because light levels were too low to stimulate deeper migrations. Alternatively, organisms normally found below $60 \mathrm{~m}$ may have entered shallower depths to take advantage of increased food. At night, upward migration may have been reduced such that the animals were more evenly distributed between 0 and $60 \mathrm{~m}$ instead of concentrated in the upper $30 \mathrm{~m}$. In sum, the higher biomass and abundance of mesozooplankton in the iron-enriched patch appeared to be largely due to a reproductive response among the copepods and small larvaceans. However, changes in the vertical migratory behaviors of mesozooplankton in response to light and/or food contributed to increased abundances in the patch, as well.

\section{Mesozooplankton grazing impact}

The increase in gut pigment content of mesozooplankton inside the patch was large and highly significant (Fig. 8). Unlike the maxima in biomass and abundance, which occurred only as the bloom was peaking on JDs 154 and 155, high levels of gut phaeopigment were measured throughout the bloom peak. Bautista \& Harris (1992) also observed a time lag between peaks in mesozooplankton abundance and gut pigments, with the latter occurring after the peak abundance, but concurrently with increasing chl a. They ascribed this lag to changes in the phytoplankton size distribution, implying that larger phytoplankton came later in the bloom and were more available to mesozooplankton due to size-selective feeding (Frost 1972, Nival \& Nival 1976, Lampitt \& Gamble 1982). This proposed mechanism is consistent with observed increases in cellular chl a content of ambient phytoplankton in the early stages of the IronEx II bloom with the shift to larger phytoplankton taxa occurring more gradually (Landry et al. 2000).

Following the measured increases in gut pigment, mesozooplankton grazing estimates increased dramatically from $\sim 0.01 \mathrm{mg} \mathrm{Ph} \mathrm{m}^{-3} \mathrm{~d}^{-1}$ outside the patch to $>0.25 \mathrm{mg} \mathrm{Ph} \mathrm{m}^{-3} \mathrm{~d}^{-1}$, and as high as $0.35 \mathrm{mg} \mathrm{Ph} \mathrm{m}^{-3} \mathrm{~d}^{-1}$ (JDs 153 to 155), in the patch. Grazing rates were high even as abundance declined inside the patch, indicating that individuals continued to respond functionally to enhanced phytoplankton throughout the bloom.

Morales et al. (1991) found that small mesozooplankton in the northeast Atlantic were more abundant than the other size classes (500-1000 and 1000-2000 $\mu \mathrm{m}$ ) and were responsible for $>50 \%$ of the overall mesozooplankton community grazing. A similar dominance of mesozooplankton grazing rate by the $200-500 \mu \mathrm{m}$ fraction has been reported in the equatorial Pacific (Dam et al. 1995). During the present study, however, the 202-500 $\mu \mathrm{m}$ mesozooplankton accounted for a consistently lower portion of the total grazing rate than the 500-2000 $\mu \mathrm{m}$ fraction (Table 4). Bautista \& Harris (1992) demonstrated that medium-sized (350-710 $\mu \mathrm{m})$ mesozooplankton contributed $>80 \%$ of the total community $(>200 \mu \mathrm{m})$ grazing rate in the temperate Atlantic waters. Possibly, the size range for the 500-2000 $\mu \mathrm{m}$ fraction in the present study was so wide that it masked the influence of the medium-sized animals by combining them with the larger organisms. 
Despite contributing less to overall mesozooplankton grazing rate than the large-size fraction, an intriguing aspect of the small-sized mesozooplankton response to the phytoplankton bloom was the increased abundances of larvaceans (appendicularia) in the 202-500 $\mu \mathrm{m}$ fraction. Although larvacean abundance is likely to be underestimated in the $>200 \mu \mathrm{m}$ net fractions, their increase during the bloom may have been an important component of the mesozooplankton grazing response. In California waters, for example, larvacean gut pigment contents and grazing impacts are comparable to and often exceed those of the more numerous copepods (Landry et al. 1994a,b). Because appendicularians produce relatively dense, fast sinking fecal pellets and discard numerous glycoprotein houses daily, their increasing presence in the IronEx II patch may also have contributed significantly to carbon export.

The present estimates of mesozooplankton grazing impact in ambient equatorial waters are reasonable with respect to the results of other studies, which range broadly from 0.10 to $18 \% \mathrm{chl}$ a standing stocks $\mathrm{d}^{-1}$, with a mean of approximately $5 \% \mathrm{~d}^{-1}$ (e.g. Bautista \& Harris 1992, Dagg 1993, Dam et al. 1993, 1995, Landry et al. 1994b). Even the elevated estimates from the patch, which average about $20 \% \mathrm{~d}^{-1}$ (specific mortality rate $=0.22 \mathrm{~d}^{-1}$ ) for the bloom peak (JDs 154 to 158), would be insufficient to suppress equatorial phytoplankton capable of growing at 1 to 2 cell divisions $\mathrm{d}^{-1}$ (e.g. Landry et al. 1995, Verity et al. 1996, Latasa et al. 1997). Nonetheless, the present inferences from gut pigments should be considered minimal or conservative estimates of grazing impact because they make no allowance for digestive destruction of the grazed chl a or the possibly that gut throughput rates increased when food became more available in the patch.

We can assess the likely magnitude of the uncertainty in the pigment-based grazing estimates by looking at the problem from another perspective. Throughout the peak of the patch bloom, where we can assume that the zooplankton should be growing at or near their maximal temperature-dependent rates, biomass-specific gut pigment contents averaged roughly $2.7 \mu \mathrm{g} \mathrm{Ph}$ $\mathrm{mg} \mathrm{C}^{-1}$ (Fig 8). At a gut clearance rate of $2.1 \mathrm{~h}^{-1}$ and a $\mathrm{C}: \mathrm{chl} a$ of 70 (Landry et al. in press), the daily rate of pigment processing would be $136 \mu \mathrm{g} \mathrm{chl} \mathrm{a} \mathrm{(mg} \mathrm{zoo-}$ plankton $\mathrm{C}^{-1} \mathrm{~d}^{-1}$, and each $\mathrm{mg}$ of mesozooplankton biomass would consume an estimated $9.5 \mathrm{mg}$ phytoplankton $\mathrm{C} \mathrm{d}^{-1}$. Therefore, the carbon ingested from phytoplankton alone should have supported a specific mesozooplankton growth rate of $0.64 \mathrm{~d}^{-1}$ assuming a gross growth efficiency (GGE) of $20 \%$, or $0.86 \mathrm{~d}^{-1}$ for GGE $=25 \%$. These estimates approach the predicted temperature-dependent growth rate of $1.0 \mathrm{~d}^{-1}$ from Huntley \& Lopez (1992) while making no allowance for additional feeding on non-pigmented prey such as other mesozooplankton and heterotrophic protists, which were also enhanced inside the patch (Landry et al. 2000). Considering these other nutritional sources, we conclude that the food resources were sufficient for high, probably maximal, rates of zooplankton biomass growth at the peak of the IronEx bloom, and that grazing rates and impacts were not seriously underestimated by our gut pigment approach and conservative assumptions.

In summary, mesozooplankton $(202-2000 \mu \mathrm{m})$ responded to the IronEx II phytoplankton bloom with significantly increased biomass, gut pigment content and grazing. Copepod reproduction was at least initially enhanced in the patch, as evident in the significant increase in naupliar abundance. Alterations in depth distributions also imply behavioral responses to increased food resources and/or diminished light. The available evidence indicates that the zooplankton were grazing and growing at maximal, or near-maximal, rates at the peak of the bloom, but population abundances and biomass declined rather than increased during this period. These results imply that the zooplankton were tightly regulated by the network of predators in the established plankton community or that their reproductive output failed to produce viable young when the food resources were dominated by diatoms.

Acknowledgements. We gratefully acknowledge the logistical support of K. Coale and the captain and crew of the RV 'Melville'. J. Hirota's assistance with taxonomic identifications is especially appreciated. This study was supported, in part, from National Science Foundation Grants OCE-9022117 and -9218152. Contributions No. 5235 from the School of Ocean and Earth Science and Technology, University of Hawai'i at Manoa, Honolulu, Hawai'i 96822, USA, and No. 560 from the US JGOFS Program.

\section{LITERATURE CITED}

Ban S, Burns C, Castel J, Chaudron Y, Christou E, Escribano R, Umani SF, Gasparini S, Ruiz FG, Hoffmeyer M, Ianora A, Kang HK, Laabir M, Lacoste A, Miralto A, Ning X, Poulet S, Rodriguez V, Runge J, Shi J, Starr M, Uye S, Wang Y (1997) The paradox of diatom-copepod interactions. Mar Ecol Prog Ser 157:287-293

Bautista B, Harris RP (1992) Copepod gut contents, ingestion rates and grazing impact on phytoplankton in relation to size structure of zooplankton and phytoplankton during a spring bloom. Mar Ecol Prog Ser 82:41-50

Bidigare RR, Ondrusek ME (1996) Spatial and temporal variability of phytoplankton pigment distributions in the central equatorial Pacific Ocean. Deep-Sea Res II 43:809-833

Bollens SM, Frost BW, Osgood K, Watts SD (1993) Vertical distributions and susceptibilities to vertebrate predation of the marine copepods Metridia lucens and Calanus pacificus. Limnol Oceanogr 38:1841-1851

Coale KH, Johnson KS, Fitzwater SE, Gordon RM, Tanner S, 
Chavez F, Ferioli L, Sakamoto C, Rogers P, Millero F, Steinberg P, Nightingale P, Cooper D, Cochlan W, Landry MR, Constantinou J, Rollwagen G, Trasvina A, Kudela R (1996) A massive phytoplankton bloom induced by an ecosystem-scale iron fertilization experiment in the equatorial Pacific Ocean. Nature 383:495-501

Conover RJ, Durvasula SR, Wang R (1986) Probable loss of chlorophyll-derived pigments during passage through the gut of zooplankton, and some of the consequences. Limnol Oceanogr 31:878-887

Dagg M (1993) Grazing by the copepod community does not control phytoplankton in the subarctic Pacific Ocean. Prog Oceanogr 32:163-183

Dam HG, Peterson WT (1988) The effect of temperature on the gut clearance rate constant of planktonic copepods. J Exp Mar Biol Ecol 123:1-14

Dam HG, Miller CA, Jonasdottir SH (1993) The trophic role of mesozooplankton at $47^{\circ} \mathrm{N}, 20^{\circ} \mathrm{W}$ during the North Atlantic bloom experiment. Deep-Sea Res 40:197-212

Dam HG, Zhang X, Butler M, Roman MR (1995) Mesozooplankton grazing and metabolism at the equator in the central Pacific: implications for carbon and nitrogen fluxes. Deep-Sea Res 42:735-756

Dessier A, Donguy JR (1985) Planktonic copepods and environmental properties of the eastern equatorial Pacific: seasonal and spatial variations. Deep-Sea Res 32:1117-1133

Donaghay PL, Liss PS, Duce RA, Kester DR, Hanson AK, Villareal T, Tindale NW, Gifford D (1991) The role of episodic atmospheric nutrient inputs in the chemical and biological dynamics of oceanic ecosystems. Oceanography 4:62-70

Foley DG, Dickey TD, McPhaden MJ, Bidigare RR, Lewis MR, Barber RT, Lindley ST, Garside C, Manov DV, McNeil JD (1997) Longwaves and primary productivity variations in the equatorial Pacific at $0^{\circ}, 140^{\circ} \mathrm{W}$. Deep-Sea Res II 44 : 1801-1826

Frost BW (1972) Effects of size and concentration of food particles on the feeding behavior of the marine planktonic copepod Calanus pacificus. Limnol Oceanogr 27:805-815

Harrison WG (1990) Nitrogen utilization of chlorophyll and primary productivity maximum layers: an analysis based on the f-ratio. Mar Ecol Prog Ser 60:85-90

Head EJH, Harris LR (1992) Chlorophyll and carotenoid transformation and destruction by Calanus spp. grazing on diatoms. Mar Ecol Prog Ser 86:229-238

Huntley ME, Lopez MDG (1992) Temperature-dependent production of marine copepods: a global synthesis. Am Nat 140:201-242

Ianora A, Poulet SA, Miralto A (1995) A comparative study of the inhibitory effect of diatoms on the reproductive biology of the copepod Temora stylifera. Mar Biol 121:533-539

Jónasdóttir SH, Kiørboe T, Tang KW, St. John M, Visser AW, Saiz E, Dam HG (1998) Role of diatoms in copepod production: good, harmless or toxic? Mar Ecol Prog Ser 172: 305-308

Kleppel GS, Pieper RE (1984) Phytoplankton pigments in the gut contents of planktonic copepods from coastal waters off Southern California. Mar Biol 78:193-198

Kudela R, Chavez FP (1996) Bio-optical properties in relation to an algal bloom caused by iron-enrichment in the equatorial Pacific. Geophys Res Lett 23:3751-3754

Laabir M, Poulet SA, Ianora A, Miralto A, Cueff A (1995) Reproductive responses of Calanus helgolandicus. II. In situ inhibition of embryonic development. Mar Ecol Prog Ser 129:97-105

Lampitt RS, Gamble JC (1982) Diet and respiration of the small planktonic marine copepod Oithona nana. Mar Biol 66:185-190
Landry MR, Peterson WK, Fagerness VL (1994a) Mesozooplankton grazing in the southern California Bight. I. Population abundances and gut pigment contents. Mar Ecol Prog Ser 115:55-71

Landry MR, Lorenzen CJ, Peterson WK (1994b) Mesozooplankton grazing in the southern California Bight. II. Grazing impact and particulate flux. Mar Ecol Prog Ser 115:73-85

Landry MR, Constantinou J, Kirshtein J (1995) Microzooplankton grazing in the central equatorial Pacific during February and August, 1992. Deep-Sea Res II 42:657-671

Landry MR, Ondrusek ME, Tanner SJ, Brown SL, Constantinou J, Bidigare RR, Coale KH, Fitzwater S (2000) Biological response to iron fertilization in the eastern equatorial Pacific (IronEx II). I. Microplankton community abundances and biomass. Mar Ecol Prog Ser 201:27-42

Landry MR, Al-Mutairi H, Selph KE, Christensen S, Nunnery $S$ (in press) Seasonal patterns of mesozooplankton abundance and biomass at Station ALOHA. Deep-Sea Res II

Latasa M, Landry MR, Schüter L, Bidigare RR (1997) Pigmentspecific growth and grazing rates of phytoplankton in the central equatorial Pacific. Limnol Oceanogr 42:405-418

Longhurst AR (1976) Vertical migration. In: Cushing DH, Walsh JJ (eds) The ecology of the seas. Blackwell Publ, Philadelphia, p 116-140

Lopez MDG, Huntley ME, Sykes PF (1988) Pigment destruction by Calanus pacificus: impact on the estimation of water column fluxes. J Plankton Res 10:715-734

Mackas D, Bohrer R (1976) Fluorescence analysis of zooplankton gut contents and an investigation of diel feeding patterns. J Exp Mar Biol Ecol 25:77-85

Martin JH, Gordon RM, Fitzwater SE (1991) The case for iron. Limnol Oceanogr 36:1793-1802

Martin JH, Coale KH, Johnson KS, Fitzwater SE, Gordon RM, Tanner SJ, Hunter CN, Elrod VA, Nowicki JL, Coley TL, Barber RT, Lindley S, Watson AJ, Van Scoy K, Law CS, Liddicoat MI, Ling R, Stanton T, Stockel J, Collins C, Anderson A, Bidigare R, Ondrusek M, Latasa M, Millero FJ, Lee K, Yao W, Zhang JZ, Friderich G, Sakamoto C, Chavez F, Buck K, Kolber Z, Greene R, Falkowski P, Chisholm SW, Hoge R, Swift R, Yungel J, Turner S, Nightingale P, Hatton A, Liss P, Tindale NW (1994) Testing the iron hypothesis in ecosystems of the equatorial Pacific Ocean. Nature 371:123-129

Mayzaud P, Razouls S (1992) Degradation of gut pigment during feeding by a subantarctic copepod: importance of feeding history and digestive acclimation. Limnol Oceanogr 37:393-404

Morales CE, Bedo A, Harris RP, Tranter PRG (1991) Grazing of copepod assemblages in the north-east Atlantic: the importance of the small size fraction. J Plankton Res 13:455-472

Napp JM, Brooks ER, Matrai P, Mullin MM (1988) Vertical distribution of marine particles and grazers. II. Relation of grazer distribution to food quality and quantity. Mar Ecol Prog Ser 50:59-72

Nival P, Nival S (1976) Particle retention of a herbivorous copepod, Acartia clausi (adults and copepodite stages): effects on grazing. Limnol Oceanogr 21:24-28

Ortner PB, Wiebe PH, Cox JL (1980) Relationships between oceanic epizooplankton distributions and the seasonal deep chlorophyll maximum in the northwestern Atlantic Ocean. J Mar Res 38:507-531

Penry DL, Frost BW (1991) Chlorophyll a degradation by Calanus pacificus: dependence on ingestion rate and digestive acclimation to food resources. Limnol Oceanogr 36:147-159

Poulet SA, Laabir M, Ianora A, Miralto A (1995) Reproductive 
response of Calanus helgolandicus. I. Abnormal embryonic and naupliar development. Mar Ecol Prog Ser 129: 85-95

Price NM, Andersen LF, Morel FMM (1991) Iron and nitrogen nutrition of equatorial Pacific plankton. Deep-Sea Res 38: 1361-1378

Roman MR, Yentsch CS, Gauzens AL, Phinney DA (1986) Grazer control of the fine-scale distribution of phytoplankton in warm-core Gulf Stream rings. J Mar Res 44:795-813

Roman MR, Dam HG, Gauzens AL, Urban-Rich J, Foley DG, Dickey TD (1995) Zooplankton variability on the equator at $140^{\circ} \mathrm{W}$ during the JGOFS EqPac study. Deep-Sea Res II 42:673-693

Strickland JDH, Parsons TR (1972) A practical handbook of seawater analysis, 2nd edn. Fish Res Board Canada, Ottawa

Editorial responsibility: Otto Kinne (Editor),

Oldendorf/Luhe, Germany
Townsend DW, Cucci TL, Berman T (1984) Subsurface chlorophyll maxima and vertical distribution of zooplankton in the Gulf of Maine. J Plankton Res 6:793-802

Verity PG, Stoecker DK, Sieracki ME, Nelson JR (1996) Microzooplankton grazing of primary production in the equatorial Pacific. Deep-Sea Res II 43:1227-1255

White JR, Zhang X, Welling LA, Roman MR, Dam HG (1995) Latitudinal gradients in zooplankton biomass in the tropical Pacific at $140^{\circ} \mathrm{W}$ during the JGOFS EqPac study: effects of El Niño. Deep-Sea Res 42:715-733

Yamaji I (1979) Illustrations of the marine phytoplankton of Japan. Hoikusha Publishing Co, Osaka

Zhang X, Dam HG, White JR, Roman MR (1995) Latitudinal variations in mesozooplankton grazing and metabolism in the central tropical Pacific during the US JGOFS EqPac study. Deep-Sea Res 42:695-714

Submitted: July 7, 1999; Accepted: December 15, 1999

Proofs received from author(s): July 10, 2000 